\title{
Rehabilitacja pacjentów po operacji wszczepienia implantów ślimakowych na przestrzeni 20. letnich doświadczeń
}

\section{Rehabilitation of patients after cochlear implantation over the course of 20 years of experience}

\author{
Anna Geremek-Samsonowicz ${ }^{1,2}$ \\ ${ }^{1}$ Instytutu Fizjologii i Patologii Słuchu, ul. Zgrupowania AK „Kampinos” 1, 01-943 Warszawa \\ 2 Światowe Centrum Słuchu i Mowy, ul. Mokra 17, Kajetany, 05-830 Nadarzyn \\ Adres autora: Anna Geremek-Samsonowicz, Instytut Fizjologii i Patologii Słuchu, \\ ul. Zgrupowania AK „Kampinos” 1, 01-943 Warszawa; tel.: 022 3118108, e-mail: a.geremek@ifps.org.pl
}

\begin{abstract}
Streszczenie
Wprowadzenie programu leczenie niedosłuchów metodą operacji wszczepienia implantów ślimakowych wymagało stworzenia programu rehabilitacji dla tej grupy pacjentów. Na przestrzeni 20. lat od pierwszej operacji, multidyscyplinarny zespół specjalistów stworzył i cały czas udoskonala program rehabilitacji dostosowując go do różnego typu pacjentów. Wynikiem pracy zespołu są coraz lepsze efekty pooperacyjnego postępowania rehabilitacyjnego.
\end{abstract}

Słowa kluczowe: implant ślimakowy • rehabilitacja

\begin{abstract}
The implementation of the hearing loss treatment with cochlear implants required creating rehabilitation program for this group of patients. Over the course of 20 years after the first surgery, a multidisciplinary team of specialists has created and is continuously improving the rehabilitation program that would suit different types of patients. As a result - postoperative outcomes of rehabilitation are getting better and better.
\end{abstract}

Key words: cochlear implant • rehabilitation

Wstęp

Polski program implantów ślimakowych rozpoczął się w lipcu 1992 roku, w Klinice Otolaryngologii Akademii Medycznej w Warszawie. Pierwszymi pacjentami, u których zastosowano systemy implantów ślimakowych byli: dorosły postlingwalny i perilingwalne dziecko [Skarżyski i wsp., 1993; Skarzyński i wsp., 1994; Geremek i wsp., 1994]. Równocześnie z działaniami medycznymi zespół rozpoczął opracowywanie programu rehabilitacji. Podstawą programu było założenia, że środkiem i narzędziem komunikacji językowej jest mowa dźwiękowa, a warunkiem jest prawidłowe funkcjonowania narządu słuchu. Uzyskana dzięki implantowi ślimakowemu percepcja słuchowa w założeniu miała być bazą do działań rehabilitacyjnych.

Założenia i program rehabilitacji po operacji wszczepienia implantu ślimakowego

Program rehabilitacji pacjentów po implantacji oparty był głównie na doświadczeniach rehabilitacji bardzo licznej grupy osób niesłyszących, korzystających z aparatów słuchowych oraz zdecydowanie mniejszej grupy pacjentów implantowanych w ośrodkach zagranicznych. W pierwszej połowie lat 90. opierano się głównie na doświadczeniach ośrodków europejskich: był to program dziecięcy z Nottingham i Hanoweru oraz program z ośrodków w Innsbrucku i Wiedniu. Jednak do końca nie byliśmy świadomi pełnych możliwości słuchowych pacjentów z implantem ślimakowym. Członkowie naszego zespołu mieli możliwości zapoznania się z pracą w poszczególnych ośrodkach. Ze względu jednak na różnice językowe nie było możliwości bezpośredniego przeniesienia programów terapeutycznych, zostały one zaadaptowane i dostosowane do specyfiki naszego języka.

Program rehabilitacji, zgodnie z pierwszymi opracowaniami, rozpoczynał się już podczas kwalifikacji pacjentów do zabiegu [Geremek i wsp., 1999]. Od początku przyjęto zasadę multidyscyplinarnego zespołu, biorącego udział w procesie leczenia za pomocą implantów ślimakowych. W skład zespołu wchodzili: lekarze otolaryngolodzy, audiolodzy, 
foniatrzy, audio-protetycy, inżynierowie akustyki, surdologopedzi, surdopedagodzy, psychologowie. Założeniem programu była też jego niejednorodność i dopasowanie przebiegu działań do indywidualnych możliwości i potrzeb pacjenta. Każdy pacjent w innym momencie życia utracił słuch lub, jak w wypadku dzieci z prelingwalnym ubytkiem słuchu, w ogóle go nie posiadał. Różnice dotyczyły przede wszystkim poziomu słuchowego, intelektualnego, umiejętności nabywania wiedzy. Wynikała stąd konieczność przystosowania programów rehabilitacji dla pacjentów dorosłych postlingwalnych i dzieci prelingwalnych oraz znacznie mniejszej grupy dorosłych prelingwalnych. Postawione cele to w wypadku dorosłych trening słuchowy, a w wypadku dzieci wychowanie słuchowe [Skarżyński i wsp., 2003].

Program rehabilitacji określono słowem "IMPLANT" zawierając w nim najważniejsze zasady:

I-NTEGRACJA

M-OTYWACJA

P-ACJENT

L-OGOPEDA

A-UDIOLOGIA

N-AUCZANIE

T-ECHNIKA

Działania rehabilitacyjne podzielone zostały na trzy poziomy, które wyznaczały jednocześnie cel pracy terapeuty $\mathrm{z}$ pacjentem:

I poziom - podstawowy - detekcja i dyskryminacja dźwięków,

II poziom - zwykłej rozmowy - identyfikacja dźwięków, szczególnie sygnałów mowy z zestawów zamkniętych,

III poziom - rozumienie mowy na drodze słuchowej w zestawach otwartych.

Przed przystąpieniem do realizacji programu jego założenia prezentowano pacjentowi a w wypadku dzieci jego rodzicom.

Przedstawione założenia były bazą warszawskiego programu rehabilitacji, który wraz z rozwojem całego programu implantacji ulegał modyfikacji. Głównym czynnikiem wpływającym na modyfikację programu była przede wszystkim zmiana i rozszerzanie kryteriów kwalifikacji do operacji wszczepienia implantu ślimakowego [Skarzyński i wsp., 1997; Skarżyński i wsp., 2000; Piotrowska i wsp., 2001]. Zmiana kryteriów to znaczne obniżenie wieku dzieci kwalifikowanych do tej metody. Gdy program rozpoczynał się 20 lat temu uznawano, że wiek optymalny do zabiegu dla dzieci prelingwalnych to 6 . rok życia, obecnie implantowane są dzieci średnio w 11/12 miesiącu życia. Ten wiek implantacji daje szanse na najlepsze efekty pooperacyjnej rehabilitacji. Dzięki systematycznie nabywanym przez zespół doświadczeniom rozszerzono kwalifikacje również na pacjentów $\mathrm{z}$ dodatkowymi obciążeniami i deficytami [Geremek i wsp., 2002; Waśkiewicz i wsp., 2012]. Możliwość stymulacji słuchowej tej grupy pacjentów pozwoliła na poprawę ich ogólnorozwojowej rehabilitacji. Kwalifikacje zaczęto rozszerzać również na pacjentów z coraz większymi resztkami słuchowymi. Grupa ta z sukcesem była rehabilitowana przy użyciu aparatów słuchowych, ale oczekiwania tych pacjentów były dużo większe, a wszczepienie implantu ślimakowego poprawiło znacznie ich odbiór dźwięków na drodze słuchowej.
Wprowadzenie w 2002 r. przez Prof. Henryka Skarżyńskiego leczenia implantem ślimakowym częściowej głuchoty u dorosłych, a następnie u dzieci, zwiększyło spektrum grup pacjentów [Skarżyński i wsp., 2006; Skarżyński i wsp., 2007]. Pacjenci objęci programem leczenia częściowej głuchoty to osoby mające deficyty słuchowe z zakresie tonów wysokich, szczególnie powyżej 2 tys. Hz (czyli jeżeli bierzemy pod uwagę dźwięki mowy są to zakresy głosek szeregu syczącego, ciszącego i szumiącego). Z uwagi na te uwarunkowania trening słuchowy musiał przenieść swój ciężar na dźwięki wysokoczęstotliwościowe [Solnica i wsp., 2012].

Obecnie Klinika Rehabilitacji obejmuje opieką rehabilitacyjną wszystkie grupy pacjentów po operacji wszczepienia implantu ślimakowego. Szczególną uwagą objęta jest grupa najmłodszych pacjentów, gdyż intensywność programu rehabilitacji w pierwszym okresie po zabiegu daje w tej grupie najlepsze efekty [Szuchnik i wsp., 1999]. W tym celu wprowadzono rehabilitację metoda terapii audytywno-werbalnej. W metodzie tej kładzie się nacisk na aktywny udział rodziców w procesie rehabilitacji. Rodzice uczestniczac konsekwentnie $\mathrm{w}$ indywidualnie prowadzonej terapii audytywno-werbalnej, stają się głównymi organizatorami rozwijania słuchania i języka mówionego swoich dzieci. To oni kreują otoczenie wspierajace nabywanie języka mówionego w ramach codziennej aktywności dziecka i włączają słuchanie i język mówiony do wszystkich obszarów życia. W porównaniu z innymi programami wczesnej rehabilitacji terapia audytywno-werbalna wymaga więc większego zaangażowania nie tylko od terapeuty, lecz także od rodziców i samych dzieci.

Wizyty w Klinice Rehabilitacji odbywają się w odpowiednich interwałach czasowych ściśle określonych i związanych $\mathrm{z}$ etapami programowania procesora mowy. Czas trwania rehabilitacji jest dopasowany do indywidualnych potrzeb pacjentów.

Obserwacje zajęć rehabilitacyjnych podczas hospitalizacji rehabilitacyjnych, turnusów rehabilitacyjnych odbywanych między innymi w Międzynarodowym Centrum Rehabilitacji w Łebie - ośrodek filialny Instytutu - umożliwiły wypracowanie schematów zajęć grupowych o różnym charakterze, szczególnie dobrze sprawdzających się w wypadku dzieci. Wprowadzono zajęcia logorytmiki, integracji sensorycznej, psychomotoryki - są to inne formy rehabilitacyjne zwiększające i przyspieszające ekspresje mowy [Szuchnik 2003; 2005].

Niezmiernie istotnym czynnikiem rehabilitacji jest jej dostępność. Od początku programu implantów ślimakowych wypracowywano różnego rodzaju formy działania, mające na celu, przeniesienie rehabilitacji najbliżej miejsca zamieszkania. Instytut organizował szkolenia, seminaria, konferencje dla różnego rodzaju specjalistów z zakresu rehabilitacji pacjentów po operacji wszczepienia implantu ślimakowego. Miało to na celu przekazanie naszego doświadczenia i stworzenie zaplecza terapeutycznego jak najbliżej miejsca zamieszkania. Prowadzone były też przez logopedów i surdopedagogów działania na terenie przedszkoli i szkół, których zadaniem było wsparcia nauczycieli i wychowawców dzieci z implantami ślimakowymi [Kosmalowa, Szuchnik, 2000]. 
Ważnym elementem prowadzonej rehabilitacji na przestrzeni minionych lat jest opieka i wsparcie psychologiczne. Pomoc psychologiczna wobec dzieci z implantem ślimakowym, zarówno kwalifikowanych do tej metody leczenia głuchoty, jak i korzystających już z CI, koncentruje się przede wszystkim na rodzicach (i rodzinie) [Kobosko, 2011]. Rodzice potrzebują różnych form profesjonalnych oddziaływań psychologicznych (psychoedukacja, psychoterapia, indywidualne sesje z psychologiem, wideotrening komunikacji) oraz nieprofesjonalnych (np. grupa wsparcia dla rodziców) - [Kosmalowa, Kobosko, 2002], by poradzić sobie z traumą diagnozy głuchoty u dziecka i jej konsekwencjami. Ważne jest urealnienie oczekiwań rodziców co do efektów wszczepienia implantu ślimakowego ich dziecku w zależności od indywidualnych możliwości dziecka i rodziny, ulegających zmianie w miarę upływu czasu i rozwoju dziecka. Dorosłe osoby postlingwalnie ogłuchłe korzystające $\mathrm{z}$ implantu ślimakowego powinny być objęte stałą ofertą pomocy psychologicznej, a nie tylko w okresie przed-i pooperacyjnym, gdyż jak pokazują badania przeprowadzone także w IFPS, osoby te gorzej funkcjonują psychospołecznie wraz z upływem czasu od momentu wszczepienia implantu ślimakowego [Kobosko i wsp., 2012]. Oferta pomocy psychologicznej powinna być skierowana również do osób dorosłych z głuchotą prelingwalną, które podejmują decyzję o implancie ślimakowym - ta grupa pacjentów boryka się niejednokrotnie z problemami wokół własnej tożsamości jako osoby głuchej, relacji interpersonalnych i partnerskich, podjęcia aktywności zawodowej i znalezienia swojego miejsca w świecie.

Coraz większa dostępność komputerów, a przede wszystkim łączy internetowych otworzyła nowe możliwości w zakresie rehabilitacji. Formą tej pracy jest „Domowa Klinika Rehabilitacji" uzupełniająca działania terapeutyczne prowadzone w Instytucie. Ideą autorskiej metody jaką jest Domowa Klinika Rehabilitacji jest umożliwienie prowadzenia długotrwałego procesu rehabilitacji w warunkach domowych [Pankowska i wsp., 2010]. Pakiet zawiera materiały multimedialne, które w przyjazny sposób uczą wykorzystywania resztek słuchowych oraz porozumiewania się mówionymi i pisanymi formami języka. Ułatwia pozyskiwanie wiedzy o świecie, przełamuje bariery w komunikacji. Warunkiem prawidłowego wykorzystania zawartych w niej treści jest odpowiednie przeszkolenie rodziców i opiekunów. Kursy takie są organizowane przez Instytut. Terapeuci wspierają działania rodziców także poprzez fachowe poradnictwo internetowe i telefoniczne, takie jak konsultacje on-line, dające możliwość przesłania i otrzymania odpowiedzi dla pacjenta czy rodziców dziecka implantowanego, ale największy przełom nastąpił po wprowadzeniu telerehabilitacji, która umożliwiła bezpośrednią obserwację pacjenta oraz modelowanie i korygowanie zachowań komunikacyjnych i językowych.

Przez 20 lat naszej pracy zdecydowanie przenieśliśmy ciężar rehabilitacji z gabinetu terapeuty do domu pacjenta. Oczywiście nadal niezmiernie ważny jest bezpośredni kontakt z terapeutą, ale łatwość dostępu do innego rodzaju rehabilitacji znacznie zwiększyła jej efektywność.

\section{Opracowanie metod i testów nabywania kompetencji słuchowych i językowych}

Równolegle z rozwojem programu rehabilitacji musiały zostać skonstruowane i przystosowane do języka polskiego narzędzia badawcze używane do oceny realizacji programu. Większość z nich była przygotowana od podstaw albo zaadaptowana do języka polskiego przez zespół - najpierw Ośrodka dla Osób Niesłyszących i Niedosłyszących „Cochlear Center”, a od 1996 roku Instytutu Fizjologii i Patologii Słuchu [Skarzyński i wsp. 2004].

Część to testy wcześniej wykorzystywane w ocenie postępów słuchowych osób niesłyszących aparatowanych, które przystosowano do oceny postępów pacjentów implantowanych.

Do baterii testów należały:

Test słuchowego różnicowania głosek /TSRG/ - różnicowanie głosek w wyrazach,

Test „Chiński Język” - różnicowanie głosek w wyrazach bez znaczenia,

Test skriningowy - oceniający punkt wyjściowy treningu oraz ocenę postępów rehabilitacji, opracowany na podstawie materiałów firmy Cochlear AG,

Test percepcji samogłosek - w wyrazach oceniający dyskryminację i identyfikację samogłosek, własne opracowanie, Test identyfikacji 12. dźwięków - test rozpoznawania 12. dźwięków $\mathrm{z}$ otoczenia stosowany u dzieci i dorosłych, własne opracowanie,

Test Onomatopeje - test do różnicowania i identyfikacji elementów suprasegmentalnych języka polskiego, własne opracowanie [Szuchnik, Słodownik-Rycaj., 2000],

Test słuchowej percepcji mowy dla dzieci - (polska wersja testu TAPS - Test of Auditory Percepion of Speech), opracowany na postawie materiałów firmy Cochlear AG i przeznaczony do badania percepcji słuchowej dzieci i młodzieży, Zestaw testów percepcyjnych procedury EARS - (Evaluation of Auditory Responses to Speech). Zestaw testów EARS służy do sprawdzania strony odbiorczej mowy i języka. [Szuchnik i wsp., 2000].

Systematyczne korzystanie z zestawów testów w kolejnych latach pozwoliło na opracowanie Profilu Słuchowych Umiejętności Pacjentów Implantowanych. Profile w sposób graficzny prezentują indywidualne wyniki pacjenta i jego osiągnięcia słuchowe na przestrzeni czasu. Prowadzenie indywidualnych profili pacjentów umożliwia monitorowanie postępów rehabilitacji, nabywania umiejętności słuchowych i komunikacyjnych. [Szuchnik i wsp., 1996; Mueller-Malesińska 1997; Skarżyński i wsp., 2004]. Obecnie Profil Słuchowych Umiejętności Pacjentów Implantowanych został przystosowany również dla pacjentów z częściową głuchotą [Pankowska i wsp., 2012].

Najnowszym narzędziem badawczym powstałym w 2008 roku dzięki współpracy z uniwersytetem w Granadzie jest polska wersja kwestionariusza LittlEars [Obrycka i wsp., 2009; Obrycka i wsp., 2010] służącego do oceny rozwoju słuchowego dzieci słyszących oraz dzieci z wadami słuchu do 2. roku życia (po operacji wszczepienia implantu ślimakowego lub korzystających $\mathrm{z}$ aparatów słuchowych). Zawiera pytania o rosnącym stopniu trudności, związane ze zmieniającymi się wraz z wiekiem reakcjami słuchowymi.

\section{Podsumowanie}

Wszczepy ślimakowe to w chwili obecnej metoda leczenia bardzo dużej grypy pacjentów dorosłych i dzieci zarówno 
z głębokimi niedosłuchami, jak i z częściową głuchotą. Obecnie mali pacjenci z prelingwalnym niedosłuchem przygotowywani są do zabiegu i operowani przed upływem pierwszego roku życia, zaraz po rozpoznaniu wady słuchu. Dzięki temu wkraczają w świat dźwięku niemal tak samo jak ich słyszący rówieśnicy. Dzieci te odbywają edukacje w szkolnictwie masowym, natomiast pacjenci dorośli wracają po zabiegu do czynnego życia zawodowego.

Program implantów ślimakowych dzięki temu, że od początku funkcjonuje w zespole interdyscyplinarnym, otworzył środowisko medyczne na współpracę z logopedami, pedagogami i psychologami. Jest to na pewno duża zmiana w podejściu do całościowego rozwiązywania problemów osób niesłyszących. Dziś nikogo nie dziwi, że na konferencjach medycznych wygłaszane są na równi z pracami medycznymi prace $\mathrm{z}$ dziedziny rehabilitacji.

Należy wspomnieć tutaj o autorach i prekursorach warszawskiego programu rehabilitacji pacjentów po operacji wszczepiania implantów ślimakowych:

Dobry duch i opiekun Doc. Maria Góralówna (1919-1995) będąca twórczynią polskiej pedoaudiologii, humanistą i osobą całkowicie oddaną leczeniu i rehabilitacji dzieci niesłyszących. To jej doświadczenia było bazą do opracowania programu rehabilitacji, testów, zasad i wskazówek rehabilitacyjnych.

\section{Piśmiennictwo:}

1. Geremek A., Skarżyński H., Kalsek O., Tomaszewska E.: Elektrostymulacja pozaślimakowych struktur drogi słuchowej jako metoda diagnostyczna w całkowitej głuchocie. Otolaryngologia Polska, 1994; 48(Supl.18): 245-47

2. Geremek A., Skarżyński H., Szuchnik J. i wsp.: Aktualne kryteria do operacji wszczepienia implantu ślimakowego. Otolaryngologia Polska, 1999; 53(Supl.30): 110-12

3. Geremek A., Szuchnik J., Skarżyński H.: Efekty programu wszczepiania implantów ślimakowych u dzieci z dodatkowymi deficytami. Audiofonologia, 2002; 22: 193-97

4. Kobosko J.: Pomoc psychologiczna słyszącym rodzicom a efektywność rehabilitacji dziecka głuchego. Otorynolaryngologia - przegląd kliniczny, 2011; 10(1): 8-14

5. Kobosko J., Pankowska A., Skarżyński H.: Strategie radzenia sobie ze stresem u osób dorosłych postlingwalnie ogłuchłych korzystających z implantu ślimakowego w porównaniu z populacją ogólną słyszących. Otolaryngologia Polska, 2012; 66(2): 132-37

6. Kosmalowa J., Kobosko J.: Grupa wsparcia dla rodziców dzieci z uszkodzonym narządem słuchu. Szkoła Specjalna, 2002; 3: $174-80$

7. Kosmalowa J., Szuchnik J.: Funkcjonowanie szkolne pacjentów implantowanych objętych programem EARS. Audiofonologia, 2000; 18: 43-48

8. Mueller-Malesińska M., Szuchnik J., Góralówna M. i wsp.: Program rehabilitacji całkowitej utraty słuchu u osób po wszczepieniu implantów ślimakowych. Otolaryngologia Polska, 1994; 48(Supl.15)

9. Mueller-Malesińska M., Geremek A., Góralówna M. i wsp.: Podstawowe założenia programu rehabilitacji dzieci po implantowaniu wszczepem ślimakowym. Otolaryngologia Polska, 1994; 48(Supl.18): 161-64
Prof. dr hab. med. Henryk Skarżyński, twórca polskiego programu implantów ślimakowych, prekursor holistycznego rozumienia problemu niedosłuchu,

Dr n. hum. Joanna Szuchnik, pracująca od początku programu, prowadząca rehabilitacje pierwszych pacjentów, następnie wieloletni kierownik Kliniki Rehabilitacji, autorka wielu publikacji na temat rehabilitacji i rozprawy doktorskiej „Badanie percepcji stuchowej u pacjentów $z$ catkowita głuchota leczonych za pomoca wszczepów ślimakowych" (2001),

Dr n. med. Małgorzata Mueller-Malesińska, której doktorat „Program rehabilitacji chorych po wszczepieniu implantu ślimakowego"(1997) posłużył do opracowania wielu programów rehabilitacji pacjentów po wszczepach,

Dr n. hum. Maria Posłuszna-Owcarz, jej rozprawa doktorska dotyczyła niezmiernie istotnych zagadnień psychologicznych pacjentów z implantami ślimakowymi „Ocena psychologiczna rehabilitacji pooperacyjnej u dzieci z calkowita gluchota leczonych za pomoca wszczepów ślimakowych"(2001).

Dwadzieścia lat to czas, który pozwolił na nabranie doświadczenia, wypracowanie własnych metod rehabilitacji, wyszkolenie kadry terapeutów i zbudowanie profesjonalnego zespołu. Jednak motywacją ewaluacji metod i programów zawsze jest pacjent, a wszelakie podejmowane działania zmierzają ku maksymalnemu podniesieniu jakości jego życia.
10. Mueller-Malesińska M., Szuchnik J., Góralówna M. i wsp.: Organizacja programu i wyniki rehabilitacji słuchu po wszczepach ślimakowych. Biuletyn Cochlear Center, 1995; 1: 97-101

11. Mueller-Malesińska M.: Wybrane zagadnienia rehabilitacji chorych po wszczepieniu implantu ślimakowego. Audiofonologia, 1997; 11: 41-50

12. Obrycka A., Pankowska A., Padilla Garc1 J.L. i wsp.: Production and evaluation of a Polish version of the LittlEars questionnaire for the assessment of auditory development in infants. Int J Pediatr Otorhinolaryngol, 2009; 73: 1035-42

13. Obrycka A., Pankowska A., Lorens A., i wsp.: Translation of the LittlEARS Questionnaire into Polish. Cochlear Implants International Proceedings of the $9^{\text {th }}$ Europen Symposium on Paediatric Cochlear Implantation, 2010; 11(Suppl.1): 340-45

14. Pankowska A., Zgoda M., Skarżyński H. i wsp.: Home Rehabilitation Clinic as a From of Support for Parents of Implanted Children. Cochlear Implants International Proceedings of the 9th Europen Symposium on Paediatric Cochlear Implantation, 2010; 11(Suppl.1): 360-63

15. Pankowska A., Solnica J., Skarżyński H.: Wykorzystywanie zmodyfikowanego profilu umiejętności słuchowych w obserwacji efektów rehabilitacji słuchu dorosłych pacjentów z częściowa głuchotą korzystających z systemu implantów ślimakowych - doniesienie wstępne, Nowa Audiofonologia, 2012; 1(1): $38-45$

16. Piotrowska A., Lorens A., Szuchnik J. i wsp.: Procedura przedoperacyjna kwalifikacji do wszczepienia implantu ślimakowego stosowana w Instytucie Fizjologii i Patologii Słuchu w Warszawie. Audiofonologia, 2000; 20: 43-50

17. Solnica J., Kobosko J., Pankowska A. i wsp.: Efektowność treningu słuchowego osób z częściową głuchotą po wszczepieniu implantu ślimakowego w ocenie pacjentów i logopedów, Nowa Audiofonologia, 2012; 1(1): 31-37 
18. Skarżyński H., Janczewski G., Geremek A. i wsp.: Pierwszy wszczep ślimakowy w Polsce. Otolaryngologia Polska, 1993; 47(5): 427-34

19. Skarżyński H., Geremek A., Szuchnik J. i wsp.: Patiens Selection protocol for cochlear Implantation. Central and East European Journal, Oto-Rhino-Laryngology and Head and Neck Surgery, 1997; 2(3-4):120-26

20. Skarżyński H., Geremek A., Mueller-Malesińska M. i wsp.: Wskazania do wszczepów ślimakowych u dzieci. Otolaryngologia Polska, 1994; 48(Supl18): 154-57

21. Skarżyński H., Janczewski G., Goralówna M. i wsp.: Wybrane problemy dotyczące programu wszczepów ślimakowych w leczeniu głuchoty. Otolaryngologia Polska, 1994; 48(Supl.18): 157-60

22. Skarżyński H., Geremek A., Szuchnik J. i wsp.: Warsaw Cochlear Implant Program from 1992 to 1999. 4th European Congress of Oto-Rhino-Laryngology Head and Neck Surgery „Past-Present-Future”. Berlin Monduzzi Editore, 2000; 163-66

23. Skarżyński H., Szuchnik J., Mueller-Malesińska M.: Implanty ślimakowe - rehabilitacja. Stowarzyszenie Przyjaciół Osób Niesłyszących i Niedosłyszących „Człowiek człowiekowi”, Warszawa, 2000

24. Skarżyński H., Lorens A., Piotrowska A., Anderson I.: Partial deafness cochlear implantation provides benefit to a new population of individuals with hearing loss. Acta Otolaryngol, 2006; 126: 934-40

25. Skarżyński H., Lorens A., Piotrowska A., Anderson I.: Partial deafness cochlear implantation in children. Int J Pediatr Otorhinolaryngol, 2007; 71: 1407-13
26. Szuchnik J., Iskra L., Słodownik-Rycaj E. i wsp.: Proces nabywania oraz pomiar umiejętności słuchowych u pacjentów implantowanych w kolejnych etapach rehabilitacji, Audiofonologia, 1996; VIII: 129-41

27. Szuchnik J., Święcicka A.: Narzędzie oceny postępów rehabilitacji u dzieci po wszczepieniu implantu ślimakowego. Audiofonologia, 1999; 15: 123-28

28. Szuchnik J., Skarzyński H., Geremek A., Zawadzki R.: Wyniki leczenia całkowitej głuchoty u małych dzieci z głuchotą prei postligwalną. Audiofonologia, 1999; 15: 117-21

29. Szuchnik J., Słodownik-Rycaj E.: Wykorzystanie „Onomatopei” w terapii pacjentów implantowanych. Audiofonologia, 2000; 18: 49-55

30. Szuchnik J., Święcicka A., Wojewódzka B., Zawadzki R.: Profil Umiejętności Słuchowych w grupie polskich dzieci włączonych do międzynarodowego programu EARS. Audiofonologia, 2000; 18: 97-102

31. Szuchnik J.: Różne drogi rozwoju słuchowego dzieci z implantami ślimakowymi - wybrane przypadki. Audiofonologia, 2003; 24: 145-56

32. Szuchnik J.: Metoda psychomotoryczna wg Procus Block w pracy z grupą dzieci implantowanych. Audiofonologia, 2005; 27 : 91-97

33. Waśkiewicz B., Geremek-Samsonowicz A., Pankowska A.: Rehabilitacja dzieci z upośledzeniem sprzężonym. Nowa Audiofonologia, 2012; 1(1): 116-18 